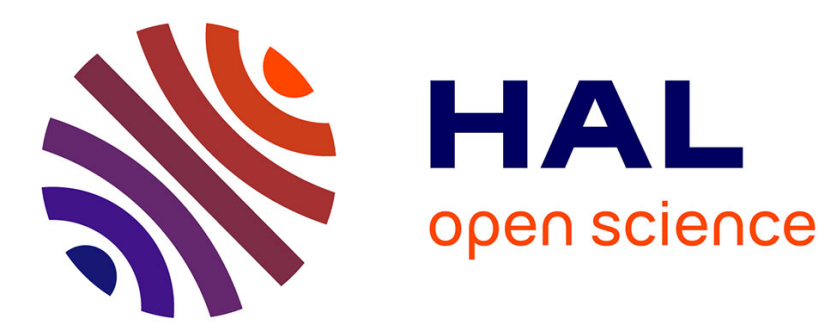

\title{
From rural to urban areas: new trends and challenges for the commons in Morocco
}

\author{
Bruno Romagny, Mohammed Aderghal, Laurent Auclair, Hélène Ilbert, \\ Sylvaine Lemeilleur
}

\section{- To cite this version:}

Bruno Romagny, Mohammed Aderghal, Laurent Auclair, Hélène Ilbert, Sylvaine Lemeilleur. From rural to urban areas: new trends and challenges for the commons in Morocco. Journal of North African Studies, 2021, pp.1-18. 10.1080/13629387.2021.2020480 . ird-03546115

\section{HAL Id: ird-03546115 https://hal.ird.fr/ird-03546115}

Submitted on 27 Jan 2022

HAL is a multi-disciplinary open access archive for the deposit and dissemination of scientific research documents, whether they are published or not. The documents may come from teaching and research institutions in France or abroad, or from public or private research centers.
L'archive ouverte pluridisciplinaire HAL, est destinée au dépôt et à la diffusion de documents scientifiques de niveau recherche, publiés ou non, émanant des établissements d'enseignement et de recherche français ou étrangers, des laboratoires publics ou privés. 
From rural to urban areas: new trends and challenges for the commons in Morocco

Author 1 Corresponding author: Bruno Romagny (Aix Marseille univ, IRD, LPED, Marseille, France), bruno.romagny@ird.fr

Author 2 Mohammed Aderghal (UM5-Rabat), m.aderghal@gmail.com

Author 3 Laurent Auclair (Aix Marseille univ, IRD, LPED, Marseille, France), laurent.auclair@univ-amu.fr

Author 4 Hélène Ilbert (CIHEAM-IAM), ilbert@iamm.fr

Author 5 Sylvaine Lemeilleur (CIRAD), sylvaine.lemeilleur@cirad.fr 


\section{From rural to urban areas: new trends and challenges for the commons in Morocco}

The concept of commons is part of the long history of the Moroccan peasantry. Traditionally, many natural resources, such as water for irrigation, collective lands and common pastures or the forests were governed by community principles derived from customary rules, like in the "agdal" system for example. However, these collective systems have been greatly weakened over the years. Firstly, these organizations, inherited from the traditional hierarchical system of local politics, had produced sometimes unjust and inefficient systems of resource distribution to the advantage of the most powerful. Secondly, rural communities were gradually stripped of their prerogatives to the benefit of the State, which was already ensuring through local power a levy on these same resources. Then, with liberalization, it is the private sector that has benefited from transformations in public policies supporting the market logic and productivist-oriented modes of organization. In this context of declining traditional natural commons, new forms of commons such as Protected Geographical Indications or Participatory Guarantee Systems are appearing through collective action, knowledge and know-how as a resource, especially in the field of food quality. Nevertheless, in a country such as Morocco, where public policies place little value on issues of ownership, involvement, and more generally on local collective initiatives, we question the role of the Moroccan government in supporting these new initiatives. While recognition of the commons is not an end in itself, it is essential to rethink the role of the State, particularly to guarantee the rights of ownership and use of resources shared by certain communities and to avoid the excesses that led to the crisis of the traditional commons.

Key words: commons; public policies; food quality; rural-urban relationships; Morocco; 


\section{Introduction}

With regard to the socio-economic mutations and ecological perspectives in many countries in the context of global change at the global scale, some scholars (Dardot \& Laval, 2015; Giraud, 2018; etc.) call to reinvent modalities of concerted management of both material (renewable natural resources) and immaterial collective resources (knowledge...) necessary to maintain the identity, the survival of people living in marginal rural areas and increasingly also in big cities, and to improve their well-being. In this perspective, we need to understand the processes through which common-pool resources are established as such if one wants to follow Dardot and Laval's proposition to re-create commons. The commons are not an end in itself and it depends on our intentions to consider them as commons. It is then the rules and institutions that are built by the community to govern the resource (material or not) that make the common work, or not (Ostrom, 1990).

The aim of this article is to question the recent evolution of different categories of commons in Morocco, starting from the transformations of traditional commons in rural areas to analyze new configurations of commons mainly linked to the reputation and quality of food products for export or domestic markets. This new kind of immaterial commons, such as Protected Geographical Indications (PGI) developed by national public authorities for the promotion of specific products (argan oil, saffron, olive oil, etc.) and territories, or Participatory Guarantee Systems (PGS) for Agroecology promoted by a Moroccan NGO, the RIAM, are questioning the capacity of collective action of different type of stakeholders along the value chains, as well as collective intelligence coming from civil society in the perspective of agro ecological transition in Morocco.

We propose to approach these issues by examining the dynamics of different types of commons, and to explore the following questions: what can we learn from the transformation of traditional commons in Morocco (collective management of water, forests, pastures, etc.), in crisis for the past thirty years, in order to analyze the emergence of new commons, based on specific knowledges, such as GI or PGS? What is the role of State and public authorities relating to the sustainability of traditional commons and to support creation of new forms of commons, linking rural and urban areas?

In a first part, we will present two case studies illustrating the crisis of the traditional commons: (i) the system of agdals; (ii) collective lands and modalities for the exercise of 
rights of use in Moroccan forest areas. We will then examine an example of re-invention of commoning practices (Bollier \& Helfrich, 2015) through the local development association of Tizi n'Oucheg. This mountain village is representative of marginal rural areas that exhibit persistence poverty, few job opportunities and acute inequality ${ }^{1}$, while the benefits of economic modernization have been concentrated in urban areas of Morocco. We can interpret this rare "success story" as the response capacity of local populations to changes in their traditional institutions. In a third and last part, through two other case studies, we will question the mobilization of intellectual commons in relation with the issue of quality of food and agricultural products. We will present various recent arrangements for the development of territorial resources in the Arganeraie (south-western part of the country), and also the test and implementation of PGS for agroecology in Rabat agglomeration and its close hinterland.

Finally, we will conclude with a brief discussion about the lessons to be drawn from these examples on the dynamics of evolution of the commons in Morocco, regarding land commons as well as intangible elements.

\section{Traditional commons under pressure in rural areas}

\section{The agdals face the transformations of the Moroccan mountains}

In Morocco, collective management of agro-sylvo-pastoral resources is part of the long history of the so-called marginal mountainous and arid areas, where farmer communities once enjoyed relative autonomy in decision-making regarding the central government (Makhzen). More recently, the agricultural strategy adopted by the Moroccan State in 2008, known as Green Morocco Plan (GMP) and, above all, its Second Pillar targets the solidarity support of small and medium-sized farmers (Inter-réseaux, 2016). These modern devices ${ }^{2}$ involve a supposedly negotiated management of common resources and/or associated know-hows. Through public action, there is a process of "opening up" these resources to private investments carried out by actors who are often foreign to the local farmers' communities.

In many marginal parts of Morocco, forestry and pastoral resources were subject to traditional and communal management, embodied by various practices often called agdal, which are still widely used today (Auclair \& Alifriqui, 2012).

\footnotetext{
${ }^{1}$ http://rgphentableaux.hcp.ma/

${ }^{2}$ Protection of forest areas, establishment of cooperatives, promotion of protected geographical indications, payments for ecosystem services, etc.
} 


\section{What is an agdal?}

An Agdal is a community-based management practice which intends to protect specific resources (pastoral, forestry, agricultural, fruit etc.) in a clearly identified and defined territory. One of the essential characteristics of the agdal is the alternation between periods of opening and closing of the territory, depending on the life cycle of plants. The agdal is a space reserved and appropriated by a social group. The managing institutions are elements of the segmented structure typical of amazighe (Berber) forms of social organization: kinship ties, villages, tribal groups of different dimensions. The community agdal is managed collectively by the local community through its customary assembly (jmaa). Many agdals are now administered at village level (douar), which is emerging as the territorial unit of reference. The frontier agdal is shared between several communities. In the past, the territory was under the guardianship of a "holy figure" and managed by a religious institution (zawiya) represented by its descendants: the holy lineages or chorfa. For several decades, the collapse of the zawiya led local authorities to intervene directly in the management and arbitration of conflicts in this type of agdal. The protection status of the agdal, "the domain of the forbidden", is until today linked to a set of values, representations and beliefs that permeate the practices of popular Islam in rural areas (Auclair \& Romagny, 2017).

\section{Ecological crisis and crisis of traditional community management institutions}

In the mountains of Morocco, the degradation of ecosystems and resources - linked in particular to pastoral over-exploitation - is worsened by the crisis of traditional regulatory systems, particularly pastoral agdals, which frequently evolve into open access situations. The causes of the weakening of agdals and of community regulations are numerous. As a result of population growth and inheritance shares, pressure on resources increases, territorial boundaries freeze, private ownership wins over collective lands. This weakens the most prized qualities of the customary regulation systems: flexibility and fluidity. The transformation of production systems ${ }^{3}$ is also a main factor of community deregulation. Confronted with major ecological problems linked to pressure on resources but also to current climate change, the intervention of the forestry administration - the only legal guarantor of

\footnotetext{
${ }^{3}$ The advance of agricultural production at the expense of agdals and best grazing lands at higher altitudes, the development of fruit trees and cash crops in irrigated areas, the transformation of pastoral practices based increasingly on speculations, etc.
} 
forest conservation and biodiversity - appears to be largely insufficient. Especially since its relationship with the rural population is historically characterized by conflictual relationships.

In recent decades, the forestry administration has attempted to renew its relationship with rural populations. Whether through the numerous projects aiming at participatory and sustainable management of resources, or the implementation of decrees regarding compensations for the protection of public forests ${ }^{4}$, or even the management of protected $\operatorname{areas}^{5}$, foresters have tried to "organize" the populations within formal local institutions (associations and cooperatives) in order to negotiate use restrictions "in exchange of" development actions or monetary compensations with them. Local associations receive nowadays additional material benefits linked to the protection of forests and biodiversity. Meanwhile, the forestry service retains its technical monopoly and the practice of agdals is not recognized any more.

In the contemporary moment, new values and aspirations invest the mountains, carried by emigrants, students, media and public institutions. Shepherding, "traditional" practices and institutions are increasingly devalued in the eyes of young people. The local authorities provide legal guardianship over the territory and intervene in the arbitration of conflicts over use in pastoral agdals. Yet an agdal "under tutorship" seems to have lost much of its flexibility and efficiency.

\subsection{Forms of livestock paths' use in the forests and peri-forest zones of central Morocco}

In the Moroccan pastoral context, the extensive nature of livestock production implies that the herd relies on natural rangelands composed of land governed under various schemes: collective, melk $^{6}$ and State-owned. These three categories form a land reserve as well as "free" resources on which the pastoral system is based, despite the hazards and crises (droughts, animal diseases).

Initially, community management of rangelands was shaped by herd mobility, as a response to climate hazards and dispersal of pastoral resources. Nowadays, while referring to identical principles, this management takes place differently. The relationship to pastoral resources has

\footnotetext{
${ }^{4}$ Decree ${ }^{\circ}$ 2-99-626.

${ }^{5}$ Law n ${ }^{\circ} 22-07$.

${ }^{6}$ A melk, registered or unregistered, equals privately owned land.
} 
in fact evolved due to changes of the land statuses. Collective land, which is subject to a process of privatization, is largely being cultivated and even opened to urbanization. State forests, in turn, are exposed to degradation, thus placed under protection or integrated into protected areas. With the dwindling of lands available for pastoral activity and the increasing scarcity of "free" resources, new forms of use of livestock tracks are emerging. They incorporate practices that relate to collective actions as well as individual strategies. Individuals in a community of forest users, or right-holders of the collective, carry out their pastoral and/or forestry activities according to a logic of profit, thus unaware of the customary principles of their community. This attitude can be found in all social categories, from the wealthy to the most deprived, who use the right of access to "free" resources to raise livestock belonging to urban investors (Aderghal \& Romagny, 2017).

The notion of commons is often used to explain the relationship between communities and the so called collective rangelands. In the meantime, a close look at the management of grass and of animals highlights a separation which makes common resources available to the most influential ${ }^{7}$. Driven by the GMP strategy, these collective rangelands have more recently been considered as land reserves permitting the opening of new frontiers to the deployment of private agricultural investments. Acquisition of land by companies and large investors, based on long-term leases, reduces the expenses linked to land, while facilitating access to other resources, in particular water. These resources are supposed to constitute collective goods in the eyes of local communities. By placing aggregation at the center ${ }^{8}$, the GMP establishes a concentration of land. This is effective in combating the fragmentation of properties, but ultimately broadens the landholdings of large farmers and risks to accelerate proletarianization of small-scale farms (Akesbi, 2012).

In a context of economic liberalism, lands in marginal areas have acquired a new market value, placing them at the center of socio-economic stakes. The questioning of the rules governing them is not a current issue. Inequalities in access to these lands gave rise to conflicts between those entitled to them. Representatives of the community (nouabs) were able to defuse these conflicts. In recent decades, women's demands, called soulalyat, to also

\footnotetext{
${ }^{7}$ Cattle, as a property of absentees who are often not entitled to be part of the collective, allows to give value to the land property through the food resource.

${ }^{8}$ One of the main objectives of the GMP is to aggregate dozens of small- and medium-scale farmers around a "leading" farmer in a process of general modernization of the production and marketing systems.
} 
have rights over these lands are to be placed in another register. These women actually challenge the customary principles that form the basis of the legislation that justifies the existence of this type of land. To claim their right to inheritance and therefore their rightholder status, they refer to Islamic jurisprudence (the chraa) which at the same time does not recognize the collective status of these lands (Ait Mouss \& Berriane, 2016). In other respects, these same customary rules are convened by groups, which are part of the communities, to justify their status as beneficiaries which has not been granted for various historical reasons ${ }^{9}$ (Aderghal \& Simenel, 2012). Through these conflicts, we see a new form of exploitation of a supposedly collective good which has become a stake in terms of privatization.

\section{What can we learn about the "success story" of Tizi n'Oucheg local development association?}

Since the 2000s, Morocco has experienced a strong associative dynamic. This enthusiasm for the associative phenomenon resonates with two major facts: on the one hand the progressive disengagement of the State from marginalized rural areas in accordance with the requirements set by the structural adjustment policies, and, on the other hand, a dynamic of disintegration of collective action in these areas (Romagny et al., 2018). Regardless of the nature of the commons mobilized at the village level (pastoral, water, etc.), social innovations - both operational and institutional - are essential to foster the maintenance of territorial commons. These social innovations often lead to hybrid forms of commons marked by institutional pluralism and new stakeholders involved, in a changing socio-economic and climate context.

The operation of the local development association of Tizi n'Oucheg perfectly illustrates this need to innovate for a rehabilitation of the commons. These innovations are marked by the shift of collective choice arenas from a customary institution (jmaa) to an associative body.

\section{Context}

Tizi n'Oucheg and its surroundings, including the Yagour plateau - a famous place of engraved landscapes in Morocco (Auclair et al., 2018), where the tradition of the agdal more or less persists - constitute a characteristic area of the High Atlas Mountains and the

\footnotetext{
${ }^{9}$ Among which: belonging to a clan of inferior social status, descendants of former slaves or families of dissidents who were dismissed for political reasons by colonial authorities when collective lands were delineated.
} 
transformations that have affected them. It is a fairly isolated and marginalized village, accessible by a drivable track, at the same time far from the basic public infrastructures (education, health, drinking water and sanitation) and located only about sixty kilometres from Marrakech, one of the main Moroccan tourist centres. The area, located on the northern side of the High Atlas of Marrakech, is characterized by the preponderance of an agropastoral mountain economy, where in recent decades tourism and diffuse urbanization have introduced some important changes. It is also a relatively accessible and open environment, where the mobility of people and goods is facilitated given the proximity of a large metropolis. It is therefore an area which is distinguished by the opportunities offered to farms - of all sizes - to access markets and take advantage of employment opportunities offered by other sectors of the local or regional economy.

In order not to be forgotten and remain at the margins, Tizi n'Oucheg is a high-mountain village that has been able to innovate by setting up new hybrid forms of development organizations. The village thus became emblematic of the self-organizing capacities of local communities. It is presented in the media ${ }^{10}$ as a textbook case of the dynamism of the associative movement in Morocco, based in particular on the development of alternative tourist activities. The village and its organization were also analyzed in a recent study (Bonnin et $a l ., 2021$ ) which looked at the dynamics of creation, destruction and modification of the commons in the Ait Oucheg territory. "The success of Tizi n'Oucheg is due to the courage of only one man, the president of his development association": this is how the message of the national and international press can be summarized. This charismatic character, both a tourism actor in the area and a "development broker" (Olivier De Sardan, 1995), occupies a central place if we want to understand the development trajectory of Tizi n'Oucheg. In a few years, he succeeded in making the local association a model based on principles of collective action and empowerment. The development of new tourism activities, which have become a real driver for collective development projects, is one of the assets of this village.

\footnotetext{
${ }^{10}$ The village of Tizi n'Oucheg and the president of its association have been the subject of several articles in the Moroccan and international press. Headlines live up to the message: «Tizi n'Oucheg, un village qui se débrouille tout seul»(Tel Quel, n 775, juillet-août 2017); «Tizi n’Oucheg, un village marocain rendu autonome par ses habitants » (https://www.wedemain.fr/Tizi-n-Oucheg-un-village-marocain-rendu-autonomepar-ses-habitants a1241.html). Tizi n'Oucheg also served as a backdrop to a documentary, co-produced by the IRD and entitled "Berbère des cimes" (http://www.audiovisuel.ird.fr/index.php?id_doc=9843).
} 


\section{Towards new commoning practices}

The Tizi n'Oucheg Development Association (TODA) was created in 2011. After the connection to the electricity network in 2000 , the TODA made it possible to continue a dynamic of development projects in a village neglected by the State. The projects, often pioneering for the region, include education, hygiene rules, access to drinking water and management of wastewater. Funding for the projects comes from different types of external actors: the municipality and the State in very small proportion, from Moroccan or foreign development associations (French in particular) which provide the majority of external resources, from the French schools of Marrakech, Rabat and Casablanca; and finally, a network of individuals mobilized on the Web in relation with touristic activities.

This dependence on external flows, such as tourism and the various resources provided by national or foreign development associations, has consequently disrupted the long-held autonomy. Indeed, various flows and exchanges have always existed, via the mobility of work towards the plains for the harvest, for example, or through the plain-mountain connexion which plays an indispensable role in maintaining the activity of animal breeding. In this perspective, to claim the mantle of an autonomous village has in itself no meaning, if not a purely marketing interest. Self-sufficiency, perpetuating poverty, is not desirable in an increasingly globalized mountain environment.

All these projects were based on a new form of associative management, gradually replacing the old forms of traditional arrangements. To understand this change, let's take the example of a village development project. In 2016, a community well was drilled with external funding and donations, mobilized through TODA. Is it the ex-nihilo birth of a "new common", or rather a displacement of the institutions of collective and operational choice? The TODA is then in charge of managing access to a new water resource. How to integrate it in a territory and a system where water is already distributed according to complex adaptive rules, inherited from the past?

These choices are no longer negotiated within the customary assembly, but within the bureau of the association, and then confronted and debated in a broader socio-political framework. Nevertheless, the association does not get rid of customary functions as regards the social distribution of water. As soon as a viable energy solution is found to pump the groundwater, it will be routed to the main basin of the village in order to integrate the traditional socio- 
hydraulic area, while waiting to find answers to questions about the use of this new resource. The TODA therefore intervenes in the management of the "traditional" commons.

Through such actions, the TODA has gradually replaced the jmaa in the management of social affairs, but also in the management of natural resources through the establishment of a dialogue between the different parties. At this stage of the work on this village, there is still a lack of understanding about this arena shift. What is the interest of customary institutions to "transfer" these powers to the TODA? How were the compromises and arrangements found between the jmaa and the association? This transition from customary management to associative governance was undoubtedly bitterly negotiated and had probably caused conflicts and tensions that should be analyzed in order to provide answers to these questions.

It is therefore not only because of the dynamics generated by the tourist activity that this relocation of arena was made possible, but also because of intense negotiation processes between heterogeneous actors. We know that some of the local stakeholders involved in village development projects were and are still part of the jmaa. A customary assembly where the stakes of power are high and the balance of power exacerbated during negotiations and arrangements. Moreover, the president of the TODA does not come from any family, but from a family of chorfa designating him as a member of the lineage of the prophet, thus giving him a very advantageous social capital to initiate new collective development projects. This also further strengthens the legitimacy of the village association.

\section{The Mobilization of intellectual commons for food quality promotion and local development}

The notion of intellectual commons - a resource of collective knowledge and know-how - is also widely mentioned today in Morocco. In the Arganeraie, we illustrate this trend by analyzing the creation of geographical indications that aim to protect and value various local terroir products (saffron, argan oil, etc.) promoted under Pillar 2 of the GMP.

Protected Designations of Origin (PDOs) and Protected Geographical Indications (PGIs) can be considered from the point of view of common property if the production and maintenance of a product's reputation bind all producers in a delimited area (Torre, 2002). The name and guidelines specifying the attributes of the product and the terroir constitute resources common to all the producers organized to defend the designation and the reputation of the product. However, the conditions for the establishment and maintenance of this designation have to 
generate links and interactions between the actors in order to guarantee strong involvement in the management of the commons (Fournier et al., 2016).

The study of the implementation conditions of the designation of origin of Taliouine saffron reveals a very low level of local stakeholders' involvement in the management of these commons, both regarding decision-making and control processes (Masrayam, 2016). Indeed, the systems depend on territorial administrations and authorities that support and accompany the aggregation of economic operators, generally cooperatives, regardless of their specifications and merely for the purpose of the sector's competitiveness. The objectives are to increase the surfaces, production volumes, packaging capacities and exports ${ }^{11}$. The topdown scheme of the controls for compliance with the guidelines reinforces the weight of the administrations and in particular that of the Ministry of Agriculture. This centralized management of PDOs and PGIs is applied to many products labeled as such in Morocco. The case of the PGI "argan oil" is no longer to be cited as an example of a resource established from the outside, reducing thus the know-how of rural women to their bare minimum: manual crushing of nuts. The argan sector emerged in the late 1990s with the creation of women's cooperatives supported by projects external to the producing territory. Private companies currently produce more than $70 \%$ of the volume of cosmetic argan oil for export. They are in a power position on the local market of the raw material and of female workforce. These dynamics are not conducive to the improvement of the right-holders' living conditions in the Arganeraie who remain far removed from the bulk of profits generated by the sector (Simenel et al., 2009; Romagny, 2010; Lybbert et al., 2011; Romagny et al., 2016).

This is the problem faced when it comes to sustainability of the actions undertaken around these PGIs in Morocco. Economic incentives favor the logic of multiplication and aggregation of cooperatives ${ }^{12}$ as well as the logic of high-technology investments by external actors (processors, analysis laboratories, etc.). In order to benefit from government subsidies, Pillar 2 of the GMP requires family farmers to "aggregate" in order to develop and implement an investment project, as if agriculture resembled any other economic sector. The call for collective action to improve the competitiveness of small-scale farmers and their capacity for

\footnotetext{
${ }^{11}$ For instance, the quantitative objectives of the saffron program contract: the cultivated area must increase from 610 to 1,350 ha, production from 3 to 9 tons, packaging from 3 to 6 tons and export from 1 to 6 tons per year (http://andzoa.ma/fr/contrats-programmes/filiere-du-safran/contrat-programme/ accessed July 18, 2016).

${ }^{12}$ In the case of saffron, between 2010 and 2014, the number of cooperatives increased 7-fold and in 2015, out of the 50 existing cooperatives, 35 operated under the designation of origin (Mutarambirwa, 2015).
} 
innovation is key to the GMP. This simplistic view of collective action does however not comply with the reality of many cooperatives (Vitry et al., 2015; Simenel et al., 2014). National political injunctions are not conducive to the establishment of rules on collective appropriation consistent with those of local stakeholders. Issues of ownership, involvement and communication are underestimated and the defense of the reputation of local products is weakened by relationships devoid of reciprocity and trust. Under these conditions, common resources are unlikely to persist; the institutional system transforms terroirs into territories of economic projects and geographical indications into organizing tools (Ilbert, 2011).

It is once again a market logic that is at work in one of the latest projects affecting the Arganeraie, entitled "Circular economy approach to preserve agro-biodiversity in the region of Souss Massa Drâa in Morocco ${ }^{13}{ }^{*}$. The long-term goal is to introduce a Payment system for Ecosystem Services (PES) as an innovative mechanism to reverse the loss and degradation of the argan ecosystem. This, in association with the promotion of two local products derived from this ecosystem: argan oil and honey. Several types of payments are being studied, of which one relates to "good practices" of planting and managing argan trees (agdal, terracing, etc.). The providers of these services are the right-holders; the beneficiaries are numerous and among them are of course the argan oil producers and consumers. In terms of readjusting the balance of power among stakeholders in the argan sector, what can be expected from such a system? How will it succeed given that other initiatives have failed? Current studies should provide some answers to these questions.

\subsection{New forms of collective action for food quality and agroecology: the example of PGS experimented in Rabat area}

Third-party certification (TPC) for organic farming labels represents a significant financial outlay for many family farms. As a result, in many parts of the world, farmers' communities are developing their own private labels and participatory guarantee systems (PGS) to certify their socially responsible eco-friendly practices. PGS is a new form of association whereby a label is governed by the community (Lemeilleur and Allaire, 2018).

\footnotetext{
${ }^{13}$ This project forms part of the cooperation between Morocco and the United Nations Development Program. It was initiated in June 2014, for a period of five years, within a framework involving many Moroccan development agencies as well as international, national and regional institutional partners.
} 
In Morocco, a growing number of farmers want urban food markets to be aware that their production practices reflect their social and ecological commitments. Simultaneously, consumers have expressed growing concern about issues of socio-environmental quality. The public regulation for Organic Agriculture in Morocco (law 39-12) entered into force in the autumn of 2018. Until that time, only certification linked to European or US standards on organic agriculture was available. These are obviously expensive and inappropriate for producers who sell their products locally. Although many Moroccan consumers have heard of organic farming, it remains a niche market nationally. According to a consumer survey (Marzouk \& Gbemenou, 2014), the main obstacles to the expansion of the organic market are linked to very high prices, the difficulty of finding organic products and the lack of information on and guarantee of production methods.

In this context, the PGS implemented by the Network of Agro-ecological Initiatives of Morocco (RIAM) has been developed to overcome these difficulties (Lemeilleur and Sermage 2020). The PGS has first been implemented in the region of Rabat, where a community of producers and consumers were already active in organic farming or agroecology through local initiatives (community-based agriculture, farmers' markets, etc.). PGS relies on peer-to-peer evaluation added to community members' evaluation to verify the compliance with the norm commitments. In the case of Moroccan PGS, this proximity and participatory certification aims to label agroecological practices. PGS allow also permanent social exchanges within the community network through regular collective farm visits, an inventory for selling outlets (markets, grocers, etc) and the opportunity to take part in the guarantee system itself. In addition, the PGS may significantly reduce the cost of certification for producers (more than 10 times cheaper than third party certification today in Morocco).

In spring 2018, the first labelling campaign of the PGS was launched. It started with 16 certified farms (7 of which are run by women) and 25 community members (including producers, consumers, restaurants, grocery stores), participating also to farm evaluation. Then PGS reached 26 certified farms in 2019 (10 of which are run by women). In 2020, 14 new farms are expecting to be PGS certified. It should be noted that four certificate holders left the PGS in 2020 for different reasons: unavailable (2), dissenting opinion (1) and loss of interest (1). 
There is no restriction a priori on the size of any individual holding. It is agroecological methods that de facto constrain the size of structures. PGS-certified products are sold mainly at the farmers' markets that have developed in Rabat. They are also sold through specialized shops in the city and through pre-ordered baskets. Today the prices of the products sold are relatively high (about 10 times higher than on the conventional market). This is mainly due to the high production costs of producers who lack training to manage risks in agro-ecological production, and who lack access to organic seeds locally (they import them if they want untreated organic seeds). Moreover, producers are still obliged to keep high prices to cover their fixed costs in a context where the low short circuit outlets do not allow them to sell their entire production. In Morocco, these producers do not benefit from any public subsidies despite the ecosystem services they provide.

It is worthwhile to note that if there is potentially also a "club" effect (which would suggest that producers voluntarily seek to sell their products at a high price), this should dissipate with the increase in the number of producers in the PGS and the development of the PGS in several cities over the next 3 years.

Beyond price, Moroccan PGS still face major challenges (Lemeilleur and Sermage, 2020). First, horizontality in collective choice overturn customary principles, in particular by restoring the place of women, who are very present in the PGS. While new rules were relatively well respected in the first start-up phase of the PGS, sustaining this mode of governance is proving to be a real challenge. New entrants should be able to express themselves and propose changes to the rules, if they feel a collective need to do so. Second, participants repeatedly expressed concerns about making it easier for smaller producers to join the PGS. A special entry system should be devised to address this issue. There are many examples of more inclusive PGS elsewhere. For instance, a support service could be implemented to help farmers fill in the administrative documents, the cost of obtaining the label could be progressive or reduced for smaller farmers (Dorville et al., 2019), a solidary fund and/or community volunteering projects could be set up at local group level (Home et al., 2017), etc. Third, all the resource's facilities (charter and specifications) have been developed based on the users' local expertise. Scholarly or academic expertise were not included. Loconto and Hatanaka (2018) show that the PGS mechanism favors farmers' knowledge, which is based on indigenous and acquired agroecological knowledge, rather than independent expert knowledge. This posture is criticized by some Moroccan stakeholders, 
who consider that the PGS community has little genuine agroecological knowledge. RIAM has thus a major role to play in terms exchanges and training related to agroecology. Fourth, like for many PGS throughout the world, securing and maintaining producer participation in a PGS is a major challenge (Nelson et al., 2010; Bellante, 2017; Kaufmann and Vogl, 2018). It is essential that stakeholders are sufficiently rewarded for their participation, be it financially or in terms of knowledge exchange and social networking. This will encourage them to stay in the PGS and invest time to maintain and develop the shared resource. Although PGS certification is significantly cheaper than TPC, it requires producers and other stakeholders to spend time doing group work and many tasks depend on voluntary work. The amount of voluntary work necessary to ensure that the PGS functions smoothly can be problematic, and we were able to observe some disparities in the levels of participation among members. Lastly, the PGS still faces challenges in Morocco, particularly regarding a change of scale and the legal recognition of this common. If the development of PGS in Morocco is compatible with the new public regulations on Organic Agriculture, producers will be allowed to switch from one system to the other depending on their target markets. However, it is impossible to predict whether public support for PGS will be forthcoming. The main threat is that the public device for organic standards could end up competing directly with the common. Another threat, that frequently occurs with knowledge commons, is the risk of misappropriation by some private actors of the PGS for their sole benefit, e.g. through intellectual property rights.

\section{Conclusion}

What lessons can we draw from the previous case studies regarding our initial questions on the evolution of the commons in Morocco, related to agricultural sector and food quality? In the cases studied, which may or may not represent characteristics of "commons", an individualization of the relationship with resources becomes evident, which is a source of conflict and/or their degradation. How are these processes of individualization triggered and accelerated by the mechanisms resulting from public policies? How are intangible commons (PDOs and PGIs), hybrids, which mobilize common material resources, leading to the exclusion and downgrading of sharing practices? Indeed, knowledge of actual sharing practices leads to the consideration of the community and the establishment of commons. 
According to the kind of issues being at stake, small group members might set up collective rules. If stakeholders do not wish to engage in collective action, it is not necessarily because they are not able to do so, but it can also result from a "rational" choice, linked to a lack of confidence in successful collective action or past bad experiences. This is particularly well illustrated in the case of common intellectual heritage resources and the difficulties encountered by certain cooperatives (Vitry et al., 2015). Since the State continues to believe that, in order to receive help, small-scale farmers have to organize themselves and regroup, how to promote other forms of collective action than the ones that have failed?

The monopolization of the commons by certain private actors, especially urban ones, further leads to an increase in inequalities, a capture of land rent and of water or fodder resources that make up their value. How are these processes of monopolization perceived, what meaning is to be given to them? Is this an unavoidable development in the liberal context, which would call for solutions based on the same market logic? Could it be that the contemporary State suffers from a form of "split personality disorder": guaranteeing, on one hand, the common goods and the equality of citizens before the law, but being, on the other hand, more and more inclined to promote private initiatives deemed to be able to withstand competition. On that matter we note that government policies put an emphasis on the principle of compensations and the orientation towards the adoption of new market instruments such as PES. The current experience in the Arganeraie indicates a renewal in the way to regulate the pressure on natural common resources in Morocco that still remains far from local governance by the communities concerned.

The recognition of the commons is certainly not an end in itself. The challenge lies more in the long-term processes involved in their founding and re-founding (Foncier \& Développement, 2015). In terms of sustainability, the qualities of the agdals for example are no longer to be theoretically demonstrated. Yet, on the ground, the actual situation is different. In general, at least in economics, the discrepancies between theory and reality of operations are striking (Pottier, 2016). The question arises as to whether the logics behind the functioning of the institutions in charge of development are simply compatible with those having carried out the slow development of practical knowledge, such as those involved in agdal. One has to notice the epistemological distance between apparently irreconcilable visions of the world. We propose therefore a two-step approach: (i) preserve and allow the autonomous logic of accumulation of the numerous concrete experiences which is at the 
origin of the progressive elaboration of knowledge; (ii) put in place validation and recognition procedures at different levels: local, national and international institutions.

Finally, what emerges from this analysis is that the notion of common goods is losing ground in rural Morocco due to the collapse of the collective system. The profound transformations under way, partly linked to the GMP, which are largely initiated and supported by public authorities, seem to contribute to the acceleration of this process. Aggregators are not the guarantors of commons if these do not comply with their private interests. The establishment of the collective by means of standardization of territorial resources through cooperatives etc. is governed by bureaucratic control constraints. The cumbersome procedures for obtaining subsidies, the challenges of competition between actors and the weak control right-holders have over the products linked to common resources obstruct the possibilities for collective action. Public action is increasingly complex, confronted with an increasing number of stakeholders on different territorial levels. Just as it is essential to better define the outlines of communities practicing collective management of shared resources, it is essential to rethink the role of the State and development policies, given that they have the power to destabilize traditional commons without proposing realistic and effective alternatives to local populations. The issues of securing rights to own and use a certain number of territories and resources are more than ever crucial in the contemporary Moroccan context.

\section{References}

Aderghal, Mohammed, et Bruno Romagny. «Terres collectives (Maroc)». 2017. In Dictionnaire des biens communs, Cornu M., Orsi F., Rochfeld J. (dir.), 1145-1147. Paris: PUF, collection « Quadrige ».

Aderghal, Mohammed, et Romain Simenel. 2012. «La construction de l'autochtonie au Maroc : des tribus indigènes aux paysans amazighs ». Espace Population Société, 2012/1: 59-72.

Aït Mouss, Fadma et Yasmine Berriane. 2016. «Femmes, droit à la terre et lutte pour l'égalité au Maroc : le mouvement des Soulaliyates ». In Contester le droit. Les communautés, familles et héritage au Maroc, Rachik H. (dir), 87-173. Casablanca : La Croisée de Chemins.

Akesbi, Najib. 2012. «Une nouvelle stratégie pour l'agriculture marocaine : Le 'Plan Maroc Vert' ». New Medit, 11 (2): 12-23.

http://www.iamb.it/share/img_new_medit_articoli/441_12_akesbi.pdf 
Auclair, Laurent et Mohamed Alifriqui M. (dir). 2012. Agdal. Patrimoine socio-écologique de l'Atlas marocain: Rabat, IRD-IRCAM éditeurs.

Auclair, Laurent, Abdehadi Ewague, et Benoit Hoarau. 2018. Les paysages gravés du HautAtlas marocain, ethnoarchéologie de l'agdal. Éditions errance, coll. «Promenades archéologiques ».

Auclair, Laurent, et Bruno Romagny. 2017. «Agdal». In Dictionnaire des biens communs, Cornu M., Orsi F., Rochfeld J. (dir.), 42-44. Paris: PUF, collection « Quadrige ».

Bellante, Laurel. 2017. «Building the Local Food Movement in Chiapas, Mexico: Rationales, Benefits, and Limitations ». Agriculture and Human Values, 34(1):119- 34. doi: 10.1007/s 10460-016-9700-9

Bollier, David, and Silke Helfrich (dir.), 2015. Patterns of communing. The Commmons Strategies Group.

Bonnin, Charles, Ayoub Elouarti, Bruno Romagny, Michel Vaillant, Geneviève Michon, Saïd Boujrouf, and Mohammed Aderghal. 2021. "Adaptation and Hybridisation of Commons in Aï Oucheg Territory, High Atlas, Morocco". Journal of Alpine Research | Revue de géographie alpine [Online], 109-1.URL: http://journals.openedition.org/rga/8528

Dardot, Pierre, et Christian Laval. 2015. Commun. Essai sur la révolution au XXI siècle. Paris: éditions La Découverte/Poche.

Dorville, Claire, Sylvaine Lemeilleur, and Paulo Niederle. 2019. Interactions Between SelfManaged Communities and Government rules: The Case of Legally Recognized PGS to Certify Agro-ecological Products in Brazil. In 13emes journées de recherche en sciences sociales INRA-SFER-CIRAD.

Foncier \& développement. 2015. «Vers la construction d'un cadre analytique et opérationnel sur les communs ». Les notes de synthèse, $\mathrm{n}^{\circ} 19$, AFD-GRET.

http://www.foncier-developpement.fr/publication/note-de-synthese-n9-vers-la-constructiondun-cadre-analytique-et-operationnel-sur-communs/

Fournier, Stéphane, Delphine Marie-Vivien, Estelle Bienabe, Claire Cerdan, Claire Durand et Denis Sautier. 2016. «Quels apports de la théorie des communs pour l'analyse des indications géographiques? », $12^{e}$ conférence internationale de l'AFD «Communs et développement», Paris, 1-2 décembre 2016.

http://communsetdeveloppementafd2016.com/uploads/event_member/116769/103fournieretaligcommun.pdf

Giraud, Gaël. 2018. «Vers une économie politique des communs ». Cités, n76, 2018/4 : 8194.

Home, Robert, Hervé Bouagnimbeck, Roberto Ugas, Markus Arbenz, and Matthias Stolze. 2017. "Participatory guarantee systems: Organic certification to empower farmers and strengthen communities". Agroecology and Sustainable Food Systems, 41(5) : 526- 545. 
Ilbert, Hélène. 2011. «Les indications géographiques, outils de construction des terroirs et de la biodiversité à l'aune des règles internationales du commerce: quelles tendances en Méditerranée ? ». In La mode du terroir et les produits alimentaires, Delfosse C. (dir.), 301321. Paris: Indes Savantes.

Inter-réseaux Développement rural. 2016. «Plan Maroc Vert, les grands principes et avancées de la stratégie agricole marocaine », Bulletin de synthèse souveraineté alimentaire, $\mathrm{n}^{\circ} 20$, 23 mai, SOS faim Belgique.

http://www.inter-reseaux.org/publications/bulletins-de-synthese/article/bulletin-de-synthese$\underline{\text { no20-plan?lang=fr }}$

Kaufmann, Sonja, and Christian R. Vogl. 2018. "Participatory Guarantee Systems (PGS) in Mexico: A Theoretic Ideal or Everyday Practice?". Agriculture and Human Values, 35(2): 457- 72. doi: 10.1007/s10460-017-9844-2.

Lemeilleur, Sylvaine, et Gilles Allaire. 2018. « Système participatif de garantie dans les labels du mouvement de l'agriculture biologique : une réappropriation des communs intellectuels ». Économie Rurale 365.

Lemeilleur, Sylvaine, and Juliette Sermage. 2020. "Building a Knowledge Commons: Evidence from the Participatory Guarantee System for an Agroecology Label in Morocco". International Journal of the Commons, 14(1): 465-480.

Loconto, Allison, and Maki Hatanaka. 2018. "Participatory Guarantee Systems : Alternative Ways of Defining, Measuring, and Assessing 'Sustainability'". Sociologia Ruralis, 58(2): 412- 432 .

Lybbert, Travis. J., Abdellah Aboudrare, Deborah Chaloud, Nicholas Magnan, and Maliha Nash. 2011. "Booming markets for Moroccan argan oil appear to benefit some rural households while threatening the endemic argan forest", Proceedings of the National Academy of Sciences, 108 (34): 13963-13968.

Marzouk H., Gbemenou B.S. 2014. Consommation des produits biologiques: analyse de marchés et comportement du consommateur marocain. Rabat: Institut Agronomique et Vétérinaire Hassan II.

Masarayam R. 2016. Mémoire bibliographique sur la gestion partagée des ressources et les facteurs déterminant l'action collective: réflexion théorique et pratique sur l'appellation d'origine du safran de Taliouine, mémoire de Master 2 recherche - Économie du développement agricole, de l'environnement et de l'alimentation, Université de MontpellierSupAgro Montpellier-CIHEAM-IAMM.

Mutarambirwa R. 2015. Study of economic impacts of geographical indications for PDO Taliouine saffron? Dissertation of Master Food Identity, ESA Angers.

Nelson, Erin, Laura Gomes Tovar, Rita Schwetesius Rindermann, and Manuel Ángel Gomes Cruz. 2010. « Participatory Organic Certification in Mexico: An Alternative Approach to 
Maintaining the Integrity of the Organic Label ». Agriculture and Human Values 27(2): 227- 37. doi: 10.1007/s10460-009-9205-x.

Olivier De Sardan, Jean-Pierre. 1995. Anthropologie et développement. GRET-Khartala.

Ostrom, Elinor. 1990. Governing the commons: the evolution of institutions for collective action. Cambridge University Press, Political Economy of institutions and decisions.

Pottier, Antonin. 2016. «Comment l'environnement transforme-t-il la discipline économique ? ». Annales des Mines - Responsabilité et environnement, 2016/3, n 83: 45-49.

Romagny, Bruno. 2010. «L'IGP Argane, entre patrimonialisation et marchandisation des ressources ». Maghreb-Machrek, $\mathrm{n}^{\circ}$ 202: 85-114.

Romagny, Bruno, Mohammed Aderghal, Laurent Auclair, Hélène Hilbert, et Sylvaine Lemeilleur. 2018. Communs en crise. Agdals, terres collectives, forêts et terroirs au Maroc. Revue internationale des études du développement, $\mathrm{n}^{\circ} 233,2018 / 1$ : 41-61.

Romagny, Bruno., Saïd Boujrouf, Noureddine Aït Errays, et Mariam Benkhallouk. 2016. « La filière 'huile d'argan' au Maroc : construction, enjeux et perspectives ». In Les terroirs au Sud, vers un nouveau modèle? Une expérience marocaine, Berriane M., Michon G. (dir.), 271-289. Rabat, Marseille: FLSH-IRD éditions.

Simenel, Romain, Geneviève Michon, Laurent Auclair, Yildiz Thomas, Bruno Romagny, et Marion Guyon. 2009. "L'argan : l'huile qui cache la forêt domestique. De la valorisation du produit à la naturalisation de l'écosystème ». Autrepart, vol. 50: 51-74.

Simenel, Romain, Bruno Romagny, et Laurent Auclair. 2014. «Les femmes berbères gardiennes des secrets de l'arganier»: le détournement des pratiques locales ». In Genre et savoirs. Pratiques et innovations rurales au Sud, Guetat-Bernard H., Saussey M. (eds. sci.), 179-200. Marseille: IRD Éditions, coll. « A travers champs ».

Torre, André. 2002. «Les AOC sont-elles des clubs ? Réflexions sur les conditions de l'action collective localisée, entre coopération et règles formelles ». Revue d'économie industrielle, vol. 100, $\mathrm{n}^{\circ}$ 1: 39-62. [Enligne].

http://www.persee.fr/doc/rei_0154-3229_2002_num_100_1_984

Vitry, Cloé, Abdellaoui El Hassane, Patrick Dugué, et Eduardo Chia. 2015. «Apprendre à coopérer : un défi pour l'adhésion des agriculteurs au Plan Maroc Vert ». New Medit, 14(2): 13-21 http://www.iamb.it/share/img_new_medit_articoli/1016_13vitry.pdf 